\title{
Parental Involvement in Children's Online Education During COVID-19; A Phenomenological Study in Saudi Arabia
}

\author{
Maryam Alharthi ${ }^{1}$ D
}

Accepted: 18 November 2021 / Published online: 22 January 2022

(c) The Author(s), under exclusive licence to Springer Nature B.V. 2021

\begin{abstract}
The global spread of COVID-19 has caused disruptions in many aspects of our lives. Education systems worldwide have changed dramatically. Numerous countries have encouraged schools to shift to e-learning and, as a result, parental involvement in their children's education has changed. This study focused on parental involvement in children's education during the COVID-19 pandemic. The study applied a qualitative phenomenological approach following a constructive social framework, whereby the researcher pursued an understanding of the world in which she lives and works. The primary tool employed to collect relevant data was in-depth interviews with six parents who voluntarily participated in the study in the western province of Saudi Arabia. Thematic analysis is applied to analyse the collected data. The study found that parental involvement in children's schooling has been affected by the COVID-19 pandemic. Furthermore, the interviews revealed that parents would prefer to keep to their chosen role rather than fulfil the teaching role imposed on them by COVID-19. This paper contributes to the application of Hoover-Dempsey and Sandler's model of parental involvement in children's schooling, illustrating that an external force drives parental involvement. More specifically, many parents have been forced to change the form of their participation due to the unforeseen shift to e-learning.
\end{abstract}

Keywords Parental involvement $\cdot$ Primary schools $\cdot$ Formal education $\cdot$ Distance learning $\cdot$ Home-schooling $\cdot$ COVID-19

\section{Introduction}

The spread of COVID-19 worldwide has forced many governments to suspend in-person schooling. According to UNESCO (2020), more than 100 countries have temporarily closed schools, which has affected $91 \%$ of students. Homeschooling has emerged as the primary substitute format, putting extra pressure on parents who were not well prepared to take on the teacher's role. According to Burgess and Sievertsen (2020), parents' productivity has been affected by the sudden change in the education system, as have children's social and academic lives. Policymakers around the world urged educational institutes to move to online learning. Teaching and learning processes changed to online and virtual methods and assessments (Burgess \& Sievertsen, 2020). Virtual and online education was adopted in Saudi Arabia, as schools were temporarily closed. Al-Khataf (2020) reported

Maryam Alharthi

Maryam.j.alharthi@gmail.com; mjharthy@taibahu.edu.sa

1 Taibah University, P.O. Box 3698,

Madinah Postcode 42364-7650, Kingdom of Saudi Arabia that homes in Saudi Arabia had turned into virtual schools to ensure that the 2019-2020 academic requirements were fulfilled.

Research on the impact of COVID-19 on students' learning outcomes is gradually emerging as researchers worldwide study the effects of COVID-19 on daily life. According to Engzell et al. (2020), the education sector does not publish data with great frequency. However, a slow, steady flow of studies in the educational field suggest that there is evidence of learning loss among students (Engzell et al., 2020; Kuhfeld et al., 2020). Other studies have shown the pandemic's impact on parents' work and their children's education (Del Boca, 2020; Yamamura \& Tsustsui, 2021). Some studies have focused on the teaching and learning process during the transfer from school-site to distance/online learning (Pajarianto et al., 2020; Putri et al., 2020). In addition, Garbe et al. (2020) explored parents' experiences in the US during the pandemic.

The purpose of this phenomenological study was to explore parental involvement in children's formal education during the suspension of schools caused by the COVID19 pandemic. This closure differed from holiday closures 
because learners were expected to continue learning online (Lancker \& Parolin, 2020). This study took place in Saudi Arabia while students were engaged in distance learning and aimed to fill a gap in research of parental involvement by considering external pressures, which appeared with the rapid change from on-site schooling to distance/online learning.

Researchers have claimed that the COVID-19 pandemic did not merely restrict students' social and academic skills but impacted their health and well-being as well. Lancker and Parolin (2020) argued that children from disadvantaged backgrounds have been severely affected by not attending school as they lost access to school lunches.

This research focused on parental involvement in children's education during the COVID-19 pandemic as well as parents' lived experiences during the suspension of inperson schooling. Parents who participated in the study were from Madinah, Saudi Arabia. During the research, some were living abroad for their studies, while the others were in Saudi Arabia. This main question led to the following sub-questions:

1. How do parents describe their parental involvement before and after the COVID-19 pandemic?

2. How did suspending in-person schooling due to COVID19 affect children socially and academically from their parents' perspectives?

3. To what extent are parents living abroad affected differently in relation to their involvement in their children's learning compared to parents residing in Madinah?

The importance of this study lies in its contribution to Hoover-Dempsey and Sandler's model of parental involvement in children's schooling, illustrating how an external force can drive parents' involvement. Specifically, many parents have been forced to change the style and extent of their involvement due to the disruption caused by COVID-19; the sudden shift to online learning has caused parental involvement to reach unprecedented levels. As all participants who engaged in this study sent their children to school before the pandemic rather than choosing an alternative method such as home-schooling, the study investigated the way parents perceived formal education during the COVID-19 pandemic. This study followed a qualitative approach. In-depth interviews explored participants' experiences of the disruption caused by the pandemic. The following section reviews the relevant literature. This review discusses formal education as a common method of educating children, briefly examines the role of technology in teaching and learning and finally, illustrates the model of parental involvement in children's education created by Hoover-Dempsey and Sandler (1995).

\section{Theoretical Background}

This study drew on the theoretical background of formal education, as it is widely acknowledged that schools are the leading providers of education. According to an article published by the World Bank (2020), education aims to ensure that all children have access to schools. This paper does not debate parents' rights to choose the type of education for their children but observes parents who have enrolled their children in formal education and how they dealt with the effects of the COVID-19 pandemic on their children's learning. This leads to the second important topic within the theoretical framework: the relationship between technology and education. Both issues have been explored in light of the parental involvement model created by Hoover-Dempsey and Sandler (1995).

\section{Formal Education and Technology}

Governments around the world support educational systems in various ways. One of the most common approaches is formal education, whereby ministries of education design and implement the policies of the education system, and students attend schools. Curriculum design is influenced by theories and drives teachers' and students' performance during the teaching and learning process. The spread of formal education differs from one country to another. In her work on formal schooling in rural Latin America, Rival (2000) claimed that formal education in this less-developed country helped produce modern citizens. Policymakers support this model of schooling, though national attitudes toward education vary between countries. In Saudi Arabia, the ministry of education is the governor's affiliation that issues and assesses educational policies and practices in state and private educational organisations (Alharthi, 2014). Education has constructed humanity's unique means of acquiring, transmitting, and producing knowledge. In today's modern society, the role of schooling as a common form of education has become the accepted norm.

Formal education practices, policies, and contexts comprise a growing field of research. Students' learning is influenced by their home situation (Lancker \& Parolin, 2020; Levinson, 2000). According to Mooij et al. (2014), parents' educational status plays a crucial role in their children's learning attainment.

The use of ICT (Information and Communication Technology) and other educational technologies in classrooms is increasing rapidly. The literature has ascertained a definite link between educational technology and positive learning outcomes. More importantly, the literature reveals 
that it is essential to have educational technology specifically designed for children by considering their needs and skills. According to McManis and Gunnewig (2012), technology plays an essential role in children's learning at an early stage, mainly when it is associated with adult guidance. Moreover, technology plays a significant role in children's daily life, and it is embodied in their learning journey in several forms. Lee (2015) claimed that welldesigned digital sources help children develop cognitive and numeracy skills.

\section{Formal Education and Distance Learning}

There was little or no opportunity to prepare for the sudden move to distance learning due to COVID-19. On-site schooling was suspended in many areas worldwide, while distance learning emerged as the inevitable way of continuing education, changing teaching and learning methods forever (Hoq, 2020). Due to the lockdowns, learners and teachers did not physically meet at school sites; instead, they utilised several learning platforms. According to Moore et al. (2011), distance learning refers to the effort of providing learning in an environment where learners are geographically distant. The shift to remote learning was largely caused by the spread of COVID-19 and the government's steps to implement national safety procedures. According to Garbe et al. (2020), some parents struggled with distance learning as it placed more pressure on them, while others felt more connected to their children's educational progress. Liu et al. (2010) pointed out that parents took on new responsibilities in distance learning as they became more engaged in their children's learning experiences. The literature has shown that distance learning was growing prior to the onset of the pandemic (Garbe et al., 2020). Parental involvement is essential in children learning experiences; the following section explores it with an emphasis on Hoover-Dempsey and Sandler's model.

\section{Parents' Involvement in Their Children's Education}

Parental involvement in their children's education is beneficial for both the children's learning and academic skills development (Durisic \& Bunijeva, 2017). Some studies have declared such a statement in general, while others have been more specific about some aspects of parental involvement (Reed et al., 2000). Parental choices cannot be adequately conceptualised in isolation from localised issues of history and geography, the psychological impact of social classes and the influences of differential access to social power and material sources (Reay, 1996).

The theoretical model shown in Fig. 1 is based on several studies conducted in the fields of psychology, education, and sociology (Reed et al., 2000). It offers a clear explanation of the process of parental involvement in their children's learning and demonstrates the various levels. Parents apply specific strategies based on their chosen level of involvement. This study attempted to contribute to this model by suggesting an extra (sixth) level in which parents experience external pressure to be involved in their children's learning, as has been the case during the COVID-19 pandemic.

This study intended to explore the role of mothers in parental involvement. This study's context was similar to that of Alharthi (2016), which took place in Saudi Arabia where the educational system is segregated and pre-primary education is linked to girls' schools, and where children of both genders are taught by female staff. A study in Italy showed that most of the additional care and household work that COVID-19 imposed fell on women (Del Boca, 2020). A study by Yamamura and Tsustsui (2021) in Japan showed that working mothers with children in primary schools were more likely than fathers to work from home during the pandemic. This difference between mothers' and fathers' engagement in their children's learning during the COVID19 pandemic is also featured in research by Spinelli et al. (2020) in which parents of children aged 2-14 years were surveyed online to explore parent and child well-being during the COVID-19 pandemic in Italy. They received 854 responses, 797 of which were completed by mothers, and the study found that the COVID-19 quarantine had a huge impact on both parents' and children's well-being. From a broader perspective, mothers tend to be more involved in their children's learning guidance and activities (Crozier, 1999).

\section{First Level: Parental Involvement Decision}

At this level, parental involvement is affected by three main factors: (1) parents' motivational beliefs (which include their sense of efficacy and their opinions regarding children's education and how they should be involved in it (Green et al., 2007; Parent Institute, 2012; Reed et al., 2000)), (2) parents' perceptions of invitations from others to be involved, such as a general invitation from the school, a specific request from a particular teacher, or an invitation from their children (Green et al., 2007; Hoover-Dempsey \& Sandler, 1995), and (3) life context variables, including parents' skills and knowledge, their time and energy for involvement and other responsibilities and commitments (Green et al., 2007).

\section{Second Level: Parental Choice of Involvement}

Sometimes, parents are driven by their skills and knowledge. The value they hold for their parental involvement is affected by a specific set of social and cultural capital that affects their choice. Alternatively, they become actively involved according to their time and energy, which is influenced by their 


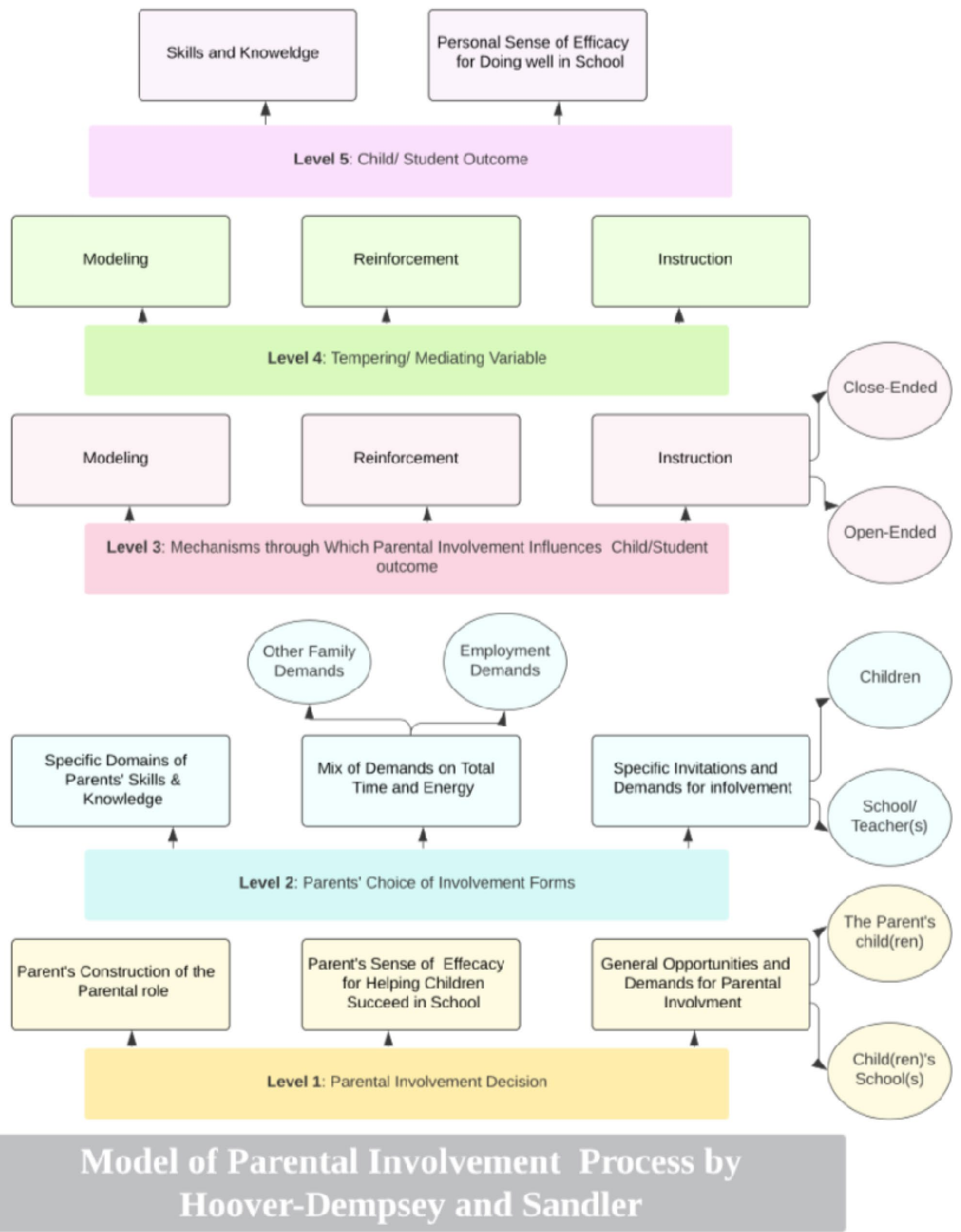

Fig. 1 Hoover-Dempsey and Sandler's model 
employment status and other family responsibilities (Green et al., 2007). At times, the decision to be involved is influenced by an outside source, such as an invitation from the children or their schools (Green et al., 2007).

\section{Third Level: Mechanisms Through Which Parental Involvement Influences Children's Outcomes}

This level illustrates the mechanisms through which parental involvement influences children's outcomes. At this level, parents decide to be involved in their children's schooling and accordingly identify the activities they want to be involved with (Hoover-Dempsey \& Sandler, 1997). According to Green et al. (2007), once they find that they have the required skills and knowledge to support their children in a particular area, parents become motivated to be involved in their children's schooling.

\section{Fourth Level: Parents' Mediating Variable}

The fourth level of parental involvement is how parents choose specific strategies to become involved in their children's learning and fit their strategies to the school's expectations (HooverDempsey \& Sandler, 1997). At this level, children become more active in learning both in and outside of school, as they have the support of their parents (Parent Institute, 2012).

\section{Fifth Level: Children's Outcomes}

The fifth level of parental involvement is where the impact of parents' participation on students' academic achievement is evident. This level includes the children's ultimate outcomes and their parents' involvement in their schooling (HooverDempsey \& Sandler, 2005).

This study looks at mothers as the leading agents involved in schooling children at home, especially in primary and preprimary levels. According to Alharthi and Lebeau (2020), mothers are responsible for deciding on the best education for their children. In their study, Alharthi and Lebeau point out that mothers play the leading role in choosing the best school for their pre-school children, as they are more engaged in their children's learning processes, especially at the pre-primary level. Moreover, in the context of the study, as explained previously, it is more straightforward for mothers to follow up with their children at the pre-school level due to the educational system in Saudi Arabia.

\section{Research Method}

\section{Research Context}

The research took place in the western province of Saudi Arabia and specifically in the city of Madinah. Saudi Arabia's educational system is unique, and in most public and private sectors, schools are segregated. Pre-schools are a female-only sector, and as explained by Alharthi (2014), mothers are more involved with their children in this stage. Moreover, from a global perspective, mothers tend to be more active when it comes to the educational market. According to Ball et al. (1996), women are most commonly, but not exclusively, at the centre of the decision-making process. Such a claim was supported when the researcher approached parents and only received responses from mothers to support their active engagement in their children's learning process. Therefore, the present study is similar to the study by Alharthi (2014) in considering mothers as active agents. However, the difference is in the way the researcher looked at their roles.

\section{Research Approach}

The present research is interpretative and was driven by a constructive social framework, whereby the researcher attempted to understand the world she lives and works in (Creswell \& Poth, 2018). This framework allowed the researcher to explore participants' views about the research topic through open-ended questions. The researcher listened carefully to the participants and related their responses to their social context to better understand their historical and social settings (Creswell \& Poth, 2018). The researcher's ontological belief is that realities are varied and constructed by individuals' lived experiences and social interaction.

Furthermore, a phenomenological approach was adopted, whereby the researcher chose specific individuals who experienced the impact of in-person schooling being suspended and depended on online schooling during the COVID-19 pandemic. In this approach, what matters most is the relationship between the participants and the phenomenon (Bowden, 2005). This research looks at mothers' parental involvement during the disruption caused by COVID-19 in the educational field. This method seemed appropriate for the present study as enabled the emphasis of similarities among participants as they experienced the phenomenon.

\section{Data Collection, Procedure, and Analysis}

The chart in Fig. 2 was adapted from Creswell and Poth's (2018) phenomenological research procedure. As the chart 


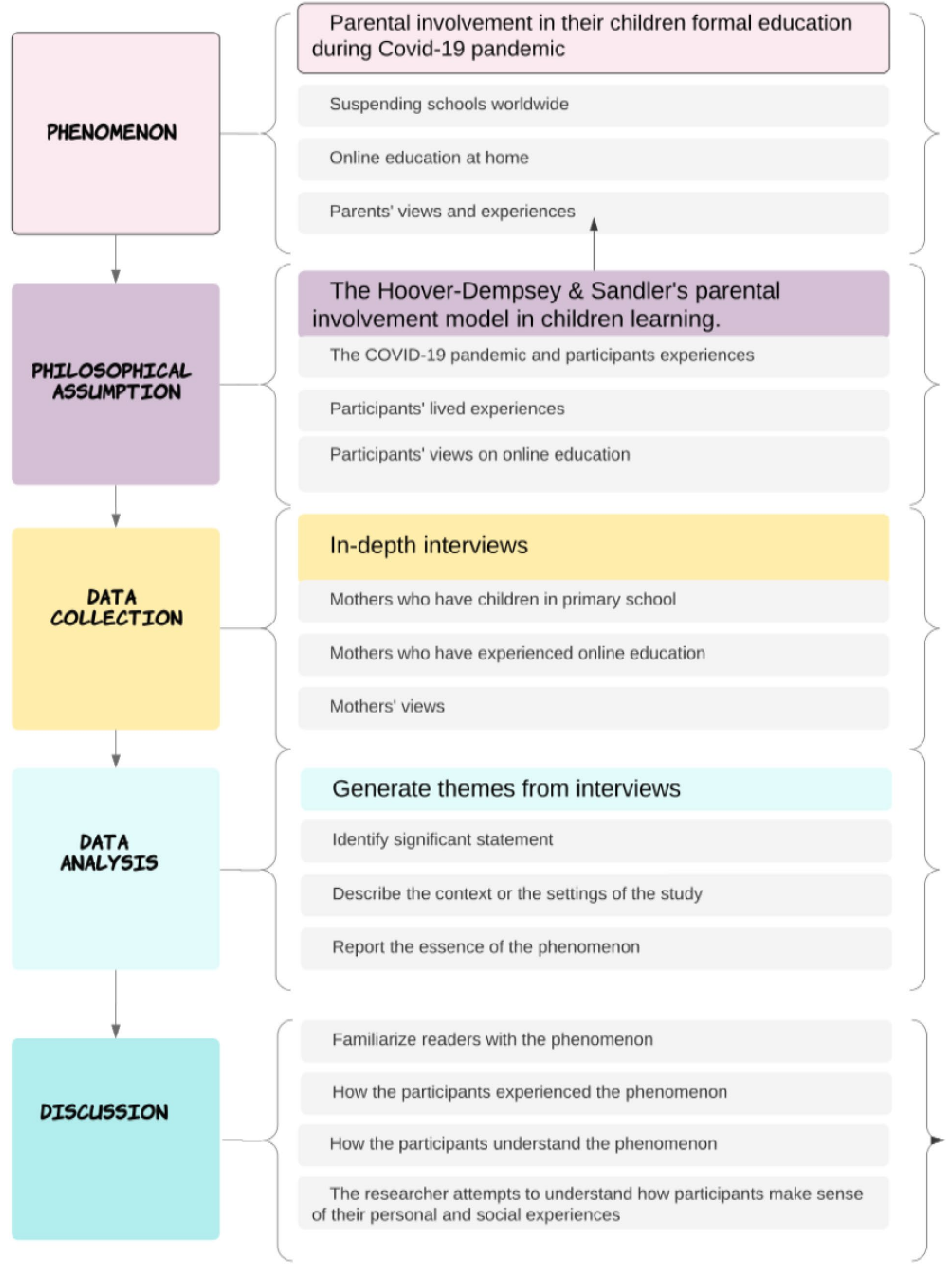

Fig. 2 Research procedure 
indicates, the present research started by studying the phenomenon's main dimensions. Then, the philosophical assumption was formulated following Hoover-Dempsey and Sandler's model on the parental involvement process. The chart then illustrates in-depth interviews as the tool of the research as well as participants' shared features. The method of analysing data-thematic analysis-is described next. Finally, the chart synthesises the discussion section in which participants' experiences are presented in light of their views, practices and, most importantly, their level of involvement.

In-depth interviews were used to collect relevant data. The data were collected at a specific time (May-July 2020) while children in Saudi Arabia were still learning at home. Creswell and Poth (2018) pointed out that interviewing is the primary research tool in phenomenological research. Six individuals were initially selected based on their common features and good understanding of parental involvement. The researcher followed the following conceptual framework to select participants:

1. Saudi mothers who were initially from the city of Madinah, Saudi Arabia.

2. Mothers who had children in the primary or pre-primary stage at the time of the study.

3. Mothers who had at least a first degree in higher education.

4. Mothers who had experienced online home education during the COVID-19 pandemic.

Since the research was framed around those four variables, only six mothers were eventually able to participate due to the social distance regulations and the partial lockdown during the data collection phase.. Due to the COVID19 circumstances participants were invited to participate through a social network medium. Prior to collecting data, a request to join the study was sent to parents, in which participants were informed that the study is confidential and they willingly volunteered to participate. Also, participants were given pseudonyms names. The responses received by the researcher were only from mothers. Hence, the focus of this paper shifted to mothers' involvement in their children's online learning during the COVID-19 pandemic. As a result, a total of 6 mothers participated in the study. Five participants had a master's degree, and one had a doctoral degree. This sample was purposefully chosen due to their common features. The participants had all experienced the research phenomenon, and had common experiences. According to Creswell and Poth (2018) in phenomenological studies, the number of individuals who experienced the phenomenon should be between 3 and 15 . The present study examined 6 well-educated mothers who were originally from Madinah city.
The study depended on online interviews, whereby data were collected through interacting 'in writing using text messaging or an online chat function' (Creswell \& Poth, 2018, p. 164). The interviews were semi-structured with an initial set of 15 questions, and many sub-questions were generated during conversations with the participants (see Appendix 1).

The scripts were analysed using thematic analysis, and MAXQDA (a qualitative data analysis software) was used to store and organise the collected data. Data were retrieved from online sources, imported to MAXQDA, and categorised in topics and themes linked directly to the study's questions. The process was similar to the one followed by Aljuwaiber (2019), as it started with coding which involved summarising segments of gathered data. Then, pattern codes were implemented to generate subthemes (Appendix 2).

All six participants had experienced the phenomenon and were able to articulate their lived experiences. At the time of the study, some were living in Saudi Arabia while others were living abroad. The research attempts to disclose how the mothers adapted to the sudden change in education within their contexts (including being mothers of young children and working or studying online).

\section{Findings and Discussion}

\section{Theme 1: Mothers' Views on the Value of Education}

This study looked at the mothers' views on the value of education from a broad perspective to investigate the impact of school closures on the parents' involvement in their children's education. The decision on the best time to enrol their children in a pre-school institution varies from mother to mother. Furthermore, it is influenced by the home situation (Mooij et al., 2014). Children's learning is influenced by their parents' educational attainment and their parent's cultural capital as well. For instance, Hanadi, a non-working mother who has a master's degree in business administration and lived in the US for several years, stated:

From my experience, I noticed that children would get the needed care from their mother - breastfeeding, caring, and affection for the first year. Then, it is appropriate for them to go to kindergarten if there is a suitable and distinguished centre in all respects. These include hygiene, care by specialists, and the presence of an educational program that develops children's skills according to their age and not only providing care. In this way, children acquire excellent skills that help them when they are old enough to go to primary school. Children not only acquire learning skills but also develop social aspects and learn the principle 
of sharing with their peers. Going to a kindergarten helps the child to arrange and organise the daily family schedule.

Hanadi did not distinguish between institutes for young children (e.g., pre-schools, care centres, and nurseries) where children learn informally in an observed and safe environment and pre-primary schools, where schooling is well-structured. Providing a clear justification of the value of early education for children, Hanadi drew on her personal experience and showed how this could affect the family's lifestyle.

Another view was provided by Fadiah, a working mother living in the US as a PhD student at the time of the study. Fadiah valued the importance of early years and provided a clear distinction between enrolling children into daycare or pre-school: 'All my kids were in daycare when they were one year old and, in a pre-school, once potty trained. Two of them were enrolled before they turned three'.

Because Fadiah was a working mother, she chose to enrol her children in day-care or childcare centres at a very young age. Hence, when she was asked about the best age to enrol a child in pre-schools, she relied on her three children's personal experiences. The mothers showed that they valued education, later reflecting on the rationale of their involvement throughout their children's online learning.

\section{Theme 2: The Importance of Parental Involvement}

The levels at which parents become involved in their children's learning processes and how they value this involvement vary from one household to another. When Sara, an assistant professor on childhood studies, explained the importance of parental involvement, she pointed out that:

It would change from parent to parent, but I think it is generally the same. At this early stage in the child's life, they are incredibly attached to their parents especially their mother. Also, it means that whatever influence the parents have on the child will stay with them forever. Imagine the positive impact it would have on the child's learning experience and their knowledge if the parents used that attachment and that special bond to build a learning environment at home a place of comfort and emotional stability, and safety. Whatever skills you instil in your child will remain with them for life.

Furthermore, by doing this, you will be encouraging the child's growth not only intellectually but also mentally and emotionally. This way, the learning process will not come to a complete halt once they leave the school door: it will continue and filter into their everyday lives. From the way they behave with others, their manners, counting skills, or whatever it may be, that knowledge and those skills they see in you as their inspirational figure will stay on. Learning could be associated not with stress but with affection, patience, and positive encouragement. It will significantly reflect on the child's self-esteem. They will feel good about themselves, and their outlook on who they are as people will be positive since their home - their place of safety and psychological upbringing - would have reinforced that. So yes, I do think it is essential for parents to play a role in the child's education, not just for the knowledge it brings to the child, but for the positive mental effect it has on their outlook and what they could bring to the world.

Sara holds a PhD in child psychology and lived in the UK with her primary school children at the time of the study. Her profession and educational background immensely influenced her views on the importance of parents' involvement in their children's learning. How she explained the difference between parents getting involved in their children's education is well supported from an academic perspective. Moreover, the fact that she highlighted the importance of parents' roles in the early stages demonstrates the power of cultural capital and how parents' views are explored. In a study in a similar context, Alharthi and Lebeau (2020) focused on exploring mothers' decisions to enrol their children in private pre-schools in Madinah. The mothers in their study were considered a minority group. In contrast, mothers in the present study represent a sector that shares a similar story with many more. In both studies, mothers are active agents either in decision-making or in parental involvement.

Amal is a Saudi mother who travelled to Australia to continue her studies during the COVID-19 pandemic. Her primary school children had been attending Australian schools, and she was in her first year of her PhD. As a working mother at a local university in Saudi Arabia in the childhood studies department, Amal's views were affected by her lived experiences:

It is essential to consider our children's progress and contact their teachers in schools. I look in my children's bags to see if they have homework. Also, I ask them what they learn in classrooms and ask about the new lessons and experiences they encounter. I believe that parental involvement in children's learning is significant for their academic achievement, high scores, behaviour, etc.

Amal, who was interested in early childhood literacy, provided a different angle on parental involvement. Her opinion reflected her area of interest, which revolved around early learning and academic achievement. Knopf and Swick (2007) pointed out that it is essential to establish relationships with families and early-years professionals to boost 
parental involvement. Being an early-years professional herself, Amal was deeply aware of the importance of her engagement in her children's schooling.

Baraa, who holds a first degree in English literature and a master's in child and family psychology, clarified how she became involved in her daughters' schooling:

I followed my daughters and put my whole effort into the early stage when they were introduced to reading and writing (pre-school level, years one and two). From year three and beyond, I made sure that they could read and write independently. I followed up with them from afar to remind them of their duties, to study and when they have tests. From time to time, I revise with them but do not follow every task or revise each subject. I tell them I am available if they need any help or if they have any questions.

I help them with what I can and some subjects. For other subjects, we seek help from family members. For example, in mathematics, for specific questions or when facing some difficulties, we turn to my sister, who has a master's degree in mathematics. She does not explain the whole curriculum again, only the problematic parts. Following up with children at the beginning is critical, but as soon as they decipher letters, I gradually pull back and let them take their learning responsibilities.

As suggested in Hoover-Dempsey and Sandler's model, parents' educational backgrounds and their lived experiences and beliefs influence the strategies they adopt to become involved in their children's schooling. Furthermore, the way the level of parental involvement declines as children advance in their schools varies. According to HooverDempsey and Sandler (2005), some parents find that their knowledge is insufficient while others prefer to build their children's independence.

The mothers involved in this study gave high regard to parental involvement. As they came from well-educated backgrounds, they tended to recognise the importance of education. Rawaa, a full-time mother who holds a degree in English literature and had her two younger children in primary school, stated that:

When [mothers] provide their children with guidance and support while they are in primary school, this has a considerable impact on their personalities and learning attitude and development. A mother's guidance at an early stage helps identify the best approach to follow with their children - whether to choose a structured, disciplined approach or a learner-centred approach depending on the child themselves.

As a mother of four children with two in primary school and two in intermediate and secondary schools, Rawaa drew on her personal experiences, which were influenced by the fact that she noticed a difference in her son and daughter's attitudes toward learning.

Even though some mothers who participated in the study were working mothers while others were non-working, both groups supported parental involvement, which may be due to the similarities in their social and cultural capital. Alharthi (2016) examined the rationale of introducing young learners to English at an early stage and found that mothers who share similar socio-cultural backgrounds have comparable attitudes toward educational choices, yet not identical depending on their individual experiences.

\section{Theme 3: The Impact of COVID-19 on Formal Education}

Suspending in-person schooling worldwide impacted the general overview of children attending them (UNESCO https://en.unesco.org/covid19/educationresponse or World Bank https://www.worldbank.org/en/data/interactive/2020/ 03/24/world-bank-education-and-covid-19). This section focuses on mothers' views on the impact of COVID-19 and the precautionary steps enacted by governments on children and their formal education.

My involvement varies by my children's age. I was able to follow up with the nine-year-old more than the younger two (three and six). My eldest was more adamant about attending the daily morning lessons. The fourth grader met the learning objectives because of the continual follow-up from his teacher and my supervision, unlike his siblings, who had two or three meetings a week, and their learning was somehow more casual.

Regarding how mothers rescheduled their daily routines to fit the new responsibility in playing a significant role, Sara claimed that:

Being a working mum, of course, has been incredibly challenging in terms of their education. Before, I would support my child's education and encourage their growth as much as possible. Nevertheless, now that I am their primary teacher, their foremost educator, it is a struggle to balance my career, my wifely duties, looking after a home, and teaching my children.

Sara provided the perspective of a working mother. She explained that she played a more active role than her husband in supporting their children's education during the COVID-19 pandemic. The ages of Sara's children are similar to those of the children discussed in the work of Yamamura and Tsustsui (2021). The researchers claim that children in primary schools affect their parents' working routines, unlike children in higher levels. 
Such change is most likely linked to how well the school activated online teaching. Each school had a different approach, which affected the way mothers became involved. For instance, Rawaa explains the steps that her children's school took to fulfil their part as the provider of knowledge:

The school activated online learning through virtual classrooms and educational portals two days after school closure. I am satisfied with their effort. Having an existing e-learning portal helped them to cope quickly with the emerging situation. The teachers follow their teaching role by strictly keeping to their daily schedule and attend their classes virtually. They also pay attention to the pupils' attendance and encourage mothers to motivate their children to attend each class.

Rawaa, who had enrolled her children in a well-known private school in Madinah, explained that some schools maintained their duties to fulfil their students' learning needs and achieve academic targets. The school infrastructure helped the teachers do their part to meet the parents' approval.

This situation was not the case for all participants. Hanadi's experience was different; when asked about her experience with her daughters' schools, she stated:

The suspension of the study and the lockdown, in general, harmed all of us. In terms of schooling, my daughters are small. The older child is in the foundation stage, and education at the foundation stage must be completed. The younger girl was bored while I was teaching her sister.

The pressure on parents to balance the different requirements of their children was enormous. They could not go to other centres, such as the English language teaching centre, because of the lockdown. The alternative was for parents to provide physical and educational activities daily around the clock.

Hanadi pointed out that the lockdown impacted the whole family as well as the activities children used to do after school. She indicated that the criteria she used to select a school for her daughter had changed due to the way schools responded to distance learning during the suspension of inperson schooling due to COVID-19. She pointed out that:

At the time of the lockdown, some schools provided educational services through their platforms. Unfortunately, my eldest daughter's school has not engaged well in the e-learning program. The teachers' role was solely to provide parents with the weekly plan. As for education and fulfilling the obligations, the pressure was on the parents. Moreover, the follow-up depended on the parents' request and urging the school to send the weekly plan. It was a challenging time. They are at the foundational stage, which is one of the new standards that parents must consider. I paid little attention to the school's e-learning strategy when I enrolled my daughter. At the time, I was not aware of the importance of such teaching; however, after the COVID-19 pandemic, it will be essential for choosing a school.

\section{Theme 4: The Impact of COVID-19 on Home-Schooling}

Schools took different approaches when facing the suspension; some schools were prepared with their established e-platforms, such as the schools attended by Rawaa's and Baraa's children. Other schools were not ready to switch to e-learning; hence, their teaching and guidance role did not meet the required level as in Hanadi's children's case.

This leads to an essential aspect of the present research, namely whether the recent change in the schooling system encourages home-schooling as a choice for parents to consider in the future.

I hope the situation returns to like before COVID-19, so my role will return to supporting my daughter's learning. For instance, I was reviewing the lessons. In that case, we can develop other extracurricular skills.

Hanadi pointed out the difference in her role as a parent when education moved to distance learning. This dimension is also referred to in the study by Garbe et al. (2020) as a lack of personal balance causing the parent to feel overwhelmed.

Although Hanadi did not have any work-related obligations, she preferred for her daughters' pre-pandemic learning scheme to resume, which relates to the Hoover-Dempsey and Sandler's model in which parents choose the extent to which they want to get involved. Hoover-Dempsey and Sandler (2005) argued that when parents choose to be involved in their children's schooling, they opt for the type of involvement that fits their routine.

During the COVID-19 pandemic, many parents found themselves inclined to get more involved than previously. Hence, the present study suggests that an extra level of parental involvement came to the fore whereby parents became involved because an external, unexpected aspect obliged them to take a further step.

\section{Theme 5: The Impact of COVID-19 on Children' Social Lives}

The suspension of in-person schooling has affected children's social development. The participants' reflections on their children's experience provide a variety of images in this regard. For instance, Fadiah claimed that the suspension influenced how her children perceived learning. They 
struggled to distinguish between their leisure time and schooling time. Furthermore, being away from their home country, missing their friends, and the lack of after-school activities affected their social interaction:

The school suspension added a comfort level that made it hard for my children to draw a line between serious learning and fun time. They found it difficult to adapt to school-related activities such as online meetings and excessive homework on technological devices. They also missed play dates and meeting their friends in person.

Fadiah managed to schedule time so her children could play online with their cousins in Saudi Arabia, which provides insight into another dimension concerning the role played by technology during COVID-19:

Children's use of technology has collided with other purposes that mainly funnelled into [children's] leisure time. The school suspension added pressure on children's perspectives on deploying technological devices to meet learning objectives (and please the parent who usually bribes with some hours of technological funrelated activity after completing the assigned work remotely).

Another perspective was provided by Sara and her family, who were also temporarily living abroad:

Apart from the education side, it has been a fantastic opportunity to spend more time with them and bond. We have learned new skills and played new games together, which has pushed us to be more creative in how we spend our time. The children are incredibly happy to be spending more time with their family, cooking, reading stories, watching films, and bonding. So, in sum, it is both a challenge and a blessing.

Having older children studying in higher education, Sara, who had additional support to enhance her children's social skills, got the most from home-schooling and created a new learning atmosphere where informal learning was encouraged.

\section{Conclusion}

This study investigated the impact of the suspension of inperson schooling during the COVID-19 pandemic from mothers' perspectives. The mothers who participated in the study came from Madinah, Saudi Arabia. At the time of the study, some of them had been living abroad due to their studies, while the others were in Saudi Arabia. The findings indicate that the mothers' levels of involvement in supporting their children's learning during the pandemic were similar.

The results demonstrate that mothers place value both on their children's education and parental involvement, especially at an early stage. The level at which parents get involved varies, even during normal circumstances; for instance, it is linked to parents' self-perceived skills and knowledge (Hoover-Dempsey \& Sandler, 2005).

The study's primary finding relates to the level at which parents found themselves involved in their children's learning due to external influences; i.e., the suspension of in-person schooling caused by the pandemic. The study's main theoretical contribution to the literature suggests that an extra level of parental involvement exists that is influenced by external forces. Imposed circumstances drive this sixth level, and in this study, this circumstance is the COVID-19 pandemic. The extra level is temporary, however; once the suddenly imposed circumstance has passed, parents are most likely to go back to the previous levels and resume their regular involvement-namely, one which suits their lifestyle.

The interviewed parents agreed that their level of involvement during the COVID-19 pandemic and school closure increased and was affected by the schools' readiness to move to e-learning. The study further demonstrated that not all schools were ready to move to e-learning. Schools' suspension of in-person learning encouraged parents to look for the e-sources that supported the national curriculum as an alternative to the schools' lack of readiness.

Limitations of this research include its focus solely on mothers' perspectives on parental involvement during the suspension and the fact that the data were collected in the early stages of the pandemic. 


\section{Appendix 1: Semi-Structured Interview Questions}

\begin{tabular}{|c|c|c|}
\hline Theme & Main questions & Subquestions \\
\hline \multirow[t]{2}{*}{ Young children } & $\begin{array}{l}\text { Do you have young } \\
\text { kids in pre-primary } \\
\text { stage? }\end{array}$ & $\begin{array}{l}\text { Were they attend- } \\
\text { ing any sort of } \\
\text { educational/ day- } \\
\text { care centres prior } \\
\text { to the COVID-19 } \\
\text { pandemic? } \\
\text { Why do you send you } \\
\text { kids to day-care? } \\
\text { How do day-care } \\
\text { centres benefit your } \\
\text { children? }\end{array}$ \\
\hline & $\begin{array}{l}\text { Do you have } \\
\text { children in early } \\
\text { primary stage? }\end{array}$ & $\begin{array}{l}\text { Were you happy with } \\
\text { their schooling prior } \\
\text { to the COVID-19 } \\
\text { pandemic? } \\
\text { Had they attended pre- } \\
\text { school before? } \\
\text { How would you relate } \\
\text { your practices as } \\
\text { mother to your own } \\
\text { experiences as a } \\
\text { young pupil? }\end{array}$ \\
\hline \multirow[t]{2}{*}{$\begin{array}{l}\text { Importance of early } \\
\text { education }\end{array}$} & $\begin{array}{l}\text { When do you think } \\
\text { is the best time } \\
\text { to enrol children } \\
\text { in an educational } \\
\text { institute? } \\
\text { How could early } \\
\text { years learning cen- } \\
\text { tres benefit your } \\
\text { child? }\end{array}$ & $\begin{array}{l}\text { Have you had the } \\
\text { same strategy with } \\
\text { all your kids? } \\
\text { Would your decision } \\
\text { change if you were a } \\
\text { working mum? }\end{array}$ \\
\hline & $\begin{array}{l}\text { How did you choose } \\
\text { your child's } \\
\text { school? }\end{array}$ & $\begin{array}{l}\text { Have your criteria } \\
\text { changed after the } \\
\text { COVID-19 pan- } \\
\text { demic? }\end{array}$ \\
\hline \multirow[t]{2}{*}{$\begin{array}{r}\text { Home-School } \\
\text { engagement }\end{array}$} & $\begin{array}{l}\text { How would you } \\
\text { describe home- } \\
\text { school engagement } \\
\text { with your chil- } \\
\text { dren's schools? }\end{array}$ & $\begin{array}{l}\text { How could such } \\
\text { engagement benefit } \\
\text { the child? } \\
\text { Who is more involved } \\
\text { in this engagement } \\
\text { from the parents? } \\
\text { Why do you think } \\
\text { mothers are more } \\
\text { involved? }\end{array}$ \\
\hline & $\begin{array}{l}\text { What is the impor- } \\
\text { tance of parents' } \\
\text { engagement with } \\
\text { the schools? }\end{array}$ & $\begin{array}{l}\text { How can parents } \\
\text { involvement change } \\
\text { due to their chil- } \\
\text { dren's age group? }\end{array}$ \\
\hline
\end{tabular}

\begin{tabular}{|c|c|c|}
\hline Theme & Main questions & Subquestions \\
\hline \multirow[t]{2}{*}{$\begin{array}{l}\text { Effect of the } \\
\text { COVID-19 pan- } \\
\text { demic }\end{array}$} & $\begin{array}{l}\text { How has your child's } \\
\text { educational institu- } \\
\text { tion responded to } \\
\text { school closure? }\end{array}$ & $\begin{array}{l}\text { Did the school/institu- } \\
\text { tion use an online } \\
\text { portal before the } \\
\text { pandemic? } \\
\text { Have you observed } \\
\text { any difficulties due } \\
\text { to the switch to } \\
\text { online education? }\end{array}$ \\
\hline & $\begin{array}{l}\text { What kind of } \\
\text { support does } \\
\text { the school offer } \\
\text { parents to adjust to } \\
\text { online learning? }\end{array}$ & $\begin{array}{l}\text { How would you } \\
\text { describe your } \\
\text { satisfaction with } \\
\text { the school's shift to } \\
\text { online learning? }\end{array}$ \\
\hline \multirow[t]{2}{*}{$\begin{array}{l}\text { The impact of } \\
\text { COVID-19 on } \\
\text { formal education }\end{array}$} & $\begin{array}{l}\text { How was your child } \\
\text { responding to } \\
\text { online education? }\end{array}$ & $\begin{array}{l}\text { How did you man- } \\
\text { age to draw a line } \\
\text { between the use of } \\
\text { technology for fun } \\
\text { and for learning? } \\
\text { How has the lockdown } \\
\text { affected your child's } \\
\text { learning? }\end{array}$ \\
\hline & $\begin{array}{l}\text { How does online } \\
\text { education affect } \\
\text { your family? }\end{array}$ & $\begin{array}{l}\text { Have your criteria for } \\
\text { choosing a school } \\
\text { for your child in the } \\
\text { future been affected } \\
\text { by the sudden switch } \\
\text { to online learning? } \\
\text { Do you prefer the level } \\
\text { of involvement you } \\
\text { had before COVID- } \\
19 \text { or during? }\end{array}$ \\
\hline \multirow[t]{2}{*}{$\begin{array}{l}\text { The impact of } \\
\text { COVID-19 on chil- } \\
\text { dren's social lives }\end{array}$} & $\begin{array}{l}\text { How has the lock- } \\
\text { down affected your } \\
\text { child's social life? }\end{array}$ & $\begin{array}{l}\text { Has the school } \\
\text { made any attempts } \\
\text { to enhance the } \\
\text { children's social } \\
\text { skills during online } \\
\text { learning? }\end{array}$ \\
\hline & $\begin{array}{l}\text { What did you do } \\
\text { to develop social } \\
\text { skills for your } \\
\text { child during the } \\
\text { lockdown? }\end{array}$ & \\
\hline
\end{tabular}




\section{Appendix 2: Thematic Coding Framework}

- Mothers' own experiences

- Elder children experience

- Early enrollment

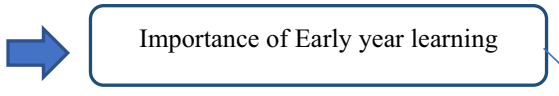

- School location

- Provided facilities

- Extra provided services

Choosing the school

Value of

education

- Developing social skills

- Developing cognitive skills

- Prepare them for future

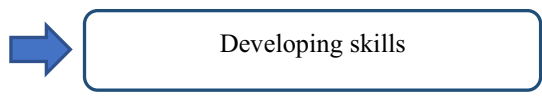

Parental

- Children's attachment

- Moral and physical

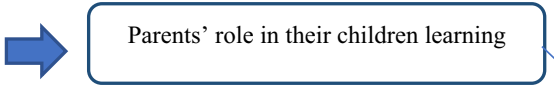

Support reading and writing skills

- Follow up their progress

- variation of involvement upon child's stage

- Virtual classrooms

- Existing platform

- unsettle switch

- Associating technology with free time

- Age-related issue

ff
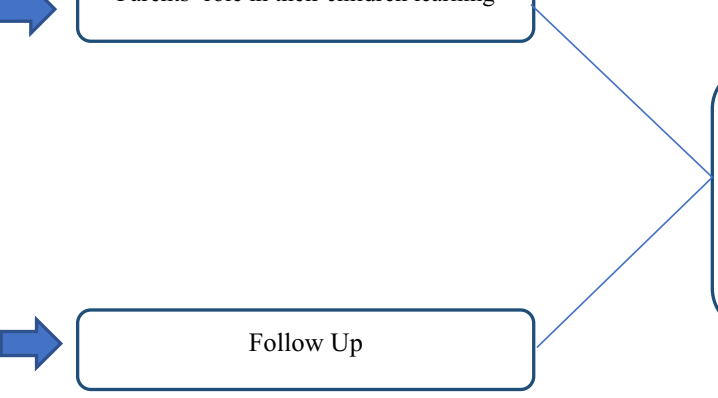

- Children miss their friends

Social skills

COVID19

\&formal

education 


\section{References}

Alharthi, M. (2014). Parental choices in early years language education. A case study of middle-class mothers in Al-Madinah, Saudi Arabia. Retrieved June 2020, from https://ueaeprints.uea.ac.uk/ id/eprint/48767/

Alharthi, M. (2016). Open sesame: A case study of the role of mothers' for their children as regards early years English education in Al-Madinah. International Journal of Education and Research, 4(12), 155-172.

Alharthi, M., \& Lebeau, Y. (2020). Preschool strategies among the Saudi middle classes: Mobilising capitals, negotiating cultural arbitraries and anticipating change. Compare: A Journal of Comparative and International Education. https://doi.org/10.1080/ 03057925.2019.1708705

Aljuwaiber, A. (2019). Technology-based vs. face-to-face interaction for knowledge sharing in the project teams. International Journal of Project Organisation and Management, 11(3), 227-242. https:// doi.org/10.1504/IJPOM.2019.10024599

Al-Khataf, I. (2020, March 10). Coronavirus turns Saudi homes into 'virtual schools'. Retrieved January 7, 2020, from https://engli sh.aawsat.com//home/article/2172682/coronavirus-turns-saudihomes-\%e2\%80\%98virtual-schools\%e2\%80\%99

Ball, S. J., Bowe, R., \& Gewirtz, S. (1996). School choice, social class and distinction: The realization of social advantage in education. Journal of Education Policy, 11, 89-112. https://doi.org/10.1080/ 0268093960110105

Boca, D. (2020). Women's and men's work, housework and childcare, before and during COVID-19. Review of Economics of Household, 18, 1001-1017.

Bowden, J. (2005). Reflections on the phenomenographic team research process. In J. Bowden \& P. Green (Eds.), Doing developmental phenomenography (pp. 11-31). RMIT University Press.

Burgess, S. \& Sievertsen, H. (2020). Schools, skills, and learning: The impact of COVID-19 on education. Retrieved June, 2020, from https://voxeu.org/article/impact-covid-19-education

Creswell, J. \& Poth, C. (2018). Qualitative inquiry and research design: Choosing among five approaches (Vol. 4). Sage.

Crozier, G. (1999). Parental involvement: Who wants it? International Studies in Sociology of Education, 9(3), 219-238. https://doi.org/ 10.1080/09620219900200045

Durisic, M., \& Bunijeva, M. (2017). Parental involvement as an important factor for successful education. CEPS Journal, 7(3), 137-153. https://doi.org/10.1007/s11150-020-09502-1

Engzell, P., Frey, A., \& Verhagen, M. (2020, October 29). Learning Loss Due to School Closures During the COVID-19 Pandemic. Retrieved from SocArXiv Papers

Garbe, A., Ogurlu, U., Logan, N., \& Cook, P. (2020). COVID-19 and remote learning: Experiences of parents with children during the pandemic. American Journal of Qualitative Research, 4(3), 45-65. https://doi.org/10.29333/ajqr/8471

Green, C., Walker, J., Hoover-Dempsey, K., \& Sandler, H. (2007). Parents' motivations for involvement in children's education: An empirical test of a theoretical model of parental involvement. Journal of Educational Psychology, 99(3), 532-544. https://doi. org/10.1037/0022-0663.99.3.532

Hoover-Dempsey, K., \& Sandler, H. (1995). Parental involvement in children's education: Why does it make a difference? Teachers College Record, 97(2), 310-331.

Hoover-Dempsey, K., \& Sandler, H. (1997). Why do parents become involved in their children's education? Review of Educational Research, 67(1), 3-42. https://doi.org/10.3102/003465430670010 03

Hoover-Dempsey, K., Walker, J., Sandler, H., Whetse, D., Green, C., Wilkins, A., \& Closson, K. (2005). Why do parents become involved? Research findings and implications. The Elementary School Journal, 106(2), 105-130. https://doi.org/10.1086/ 499194

Hoq, M. (2020). E-Learning during the period of pandemic (COVID19) in the Kingdom of Saudi Arabia: An empirical 2691/education-8-7-2. https://doi.org/10.12691/education-8-7-1

Knopf, H., \& Swick, K. (2007). How parents feel about their child's teacher/school: Implications for early childhood professionals. Early Childhood Education Journal, 34(4), 290-296. https://doi. org/10.1007/s10643-006-0119-6

Kuhfeld, J. M., Soland, J., Tarasawa, B., Johnson, A., Ruzek, E., \& Liu, J. (2020). Projecting the potential impacts of COVID-19 school closures on academic achievement. Educational Researcher, 49(8), 549-565. https://doi.org/10.3102/0013189X20965918

Lancker, W. V., \& Parolin, Z. (2020). COVID-19, school closures, and child poverty: A social crisis in the making. The Lancet, 5(5), E243-E244.

Lee, L. (2015). Digital media and young children's learning: A case study of using iPads in American preschools. International Journal of Information and Education Technology, 5(12), 947-950. https://doi.org/10.7763/IJIET.2015.V5.643

Levinson, B. (2000). Whither the symbolic animal? Society, culture, and education at the millennium. In B. Levinson (Ed.), Schooling the symbolic animal: Social and cultural dimensions of education (pp. 1-12). Rowman and Littlefield Publishers.

Liu, F., Black, E., Algina, J., Cavanaugh, C., \& Dawson, K. (2010). The validation of one parental involvement measurement in virtual schooling. Journal of Interactive Online Learning, 9(2), 105-132.

McManis, L., \& Gunnewig, S. (2012). Finding the education in educational technology with early learners. Young Children, 67(3), $14-24$.

Mooij, T., Dijkstra, E., Walraven, A., \& Kirschner, P. (2014). Towards optimal education including self-regulated learning in technologyenhanced preschools and primary schools. European Educational Research Journal, 13(5), 529-552. https://doi.org/10.2304/eerj. 2014.13.5.529

Moore, J., Dickson-Deane, C., \& Galyen, K. (2011). e-Learning, online learning, and distance learning environments: Are they the same? Internet and Higher Education, 14, 129-135. https://doi.org/10. 1016/j.iheduc.2010.10.001

Pajarianto, H., Kadir, A., Galugu, N., Sari, P., \& Februanti, S. (2020). Study from home in the middle of the COVID-19 pandemic: Analysis of religiosity, teacher, and parents support against academic stress. Talent Development \& Excellence, 12(2s), 1791-1807.

Parent Institute. (2012). Why is parent involvement important? HooverDempsey \& Sandler model of the parental involvement process. Retrieved March 2020, from Parent Institute: http://www.par-inst. com/pdf-samples/h-d-and-s-model.pdf

Putri, R. S., Purwanto, A., Pramono, R., Asbari, M., Wijayanti, L. M., $\&$ Wijayanti, C. C. (2020). Impact of the COVID-19 pandemic on online home learning: An explorative study of primary schools in Indonesia. International Journal of Advanced Science and Technology, 29(5), 4809-4818.

Reay, D. (1996). Contextualising choice: Social power and parental involvement. British Educational Research Journal, 22, 431-448. https://doi.org/10.1080/0141192960220505

Reed, R., Jones, K., Walker, J., \& Hoover-Dempsey, K. (2000). Parents' motivations for involvement in children's education: Testing a theoretical model. At the Annual Meeting of the American Educational Research Association2-19.Vanderbilt University. https:// doi.org/10.1037/0022-0663.99.3.532

Rival, L. (2000). Formal schooling and the production of modern citizens in the Ecuadorian Amazon. In B. Levinson, Schooling the Symbolic Animal: Social and Cultural Dimensions of Education, 10, 108-122. 
Spinelli, M., Lionetti, F., Pastore, M., \& Fasolo, M. (2020). Parents' stress and children's psychological problems in families facing the COVID-19 outbreak in Italy. Frontiers in Psychology, 11, $1-7$. https://doi.org/10.3389/fpsyg.2020.01713

The World Bank. (2020, April 13). Understanding poverty. Retrieved February 2020, from https://www.worldbank.org/en/topic/educa tion/overview\#2

UNESCO. (2020, March 24). School closures caused by Coronavirus (COVID-19). https://en.unesco.org/covid19/educationresponse
Yamamura, E., \& Tsustsui, Y. (2021). The impact of closing schools on working from home during the COVID-19 pandemic: Evidence using panel data from Japan. Review of Economics of the Household, 19, 41-60. https://doi.org/10.1007/s11150-020-09536-5

Publisher's Note Springer Nature remains neutral with regard to jurisdictional claims in published maps and institutional affiliations. 